\title{
RITUAL PATANITI ( STUDI BUDAYA MASYARAKAT DI JAZIRAH LEIHITU KABUPATEN MALUKU TENGAH)
}

\author{
Mujadid Naya \& Ismail Solissa \\ Fakultas Ushuluddin dan Dakwah IAIN Ambon \\ *) E-mail: mujaddidnaya1973@gmail.com
}

\begin{abstract}
Singer study entitled "Ritual Pataniti (Cultural Studies Society in Central Maluku district Leihitu Peninsula. Searching Google Articles How Pola Ritual subject matter Pataniti As Jazirah Leihitu Culture Society in Central Maluku district. Singer Research operates research is qualitative WITH deskretif using a sociological approach, and historical. The informant Of Research Singer is a religious figure, traditional leaders and community that knows the issue studied. Research shows that the singer Ritual Pataniti As Jazirah Leihitu Culture Society in Central Maluku district. Seen ASPECTS From; (1) Process, Form and Perestiwa Ritual Pataniti That Shape And pristiwa Ritual Pataniti ie when ADA Musing OR Gen Yang Yang ADA society menimpah People in the village, (2) .Makna and Culture Pataniti For 'community Jazirah (Morella Villages And Hila), Was A customs Confidence shown to the spirits Datuk-Datuk Yang ADA since PT WORKS OF HUMAN SON time. Believe kepada Allah and Muhammad, believe kepada kita Also sacred And the spirits of the ancestors lieutenant OR BECAUSE they have magical powers supernatural OR That can be helped 'The community is experiencing a disaster. (3), Ritual Pataniti WITH Values of Islamic teachings. For the ritual 'in society Jazirah The key: NO apart from the teachings of Islam. Lumped Pataniti WITH istighatsah, Which means in the name Calling Someone for review asking for help. ON ia intrinsically allowed for a Muslim, believer, Salih, and has an equalizer with Allah.
\end{abstract}

Keywords: Pataniti, Culture Society Jazirah Leihitu

ABSTRAK

Penelitian ini berjudul "Ritual Pataniti ( Studi Budaya Masyarakat di Jazirah Leihitu Kabupaten Maluku Tengah. Dengan pokok masalah Bagaimana Pola Ritual Pataniti Sebagai Budaya Masyarakat di Jazirah Leihitu Kabupaten Maluku Tengah. Jenis penelitian ini adalah penelitian deskretif kualitatif dengan menggunakan pendekatan sosiologis, dan historis. Adapun informan dari penelitian ini adalah Tokoh Agama, tokoh adat dan masyarakat yang mengetahui masalah yang dikaji. Hasil Penelitian ini menunjukan bahwa Ritual Pataniti Sebagai Budaya Masyarakat di Jazirah Leihitu Kabupaten Maluku Tengah. dilihat dari aspek; (1) Proses, Bentuk dan Perestiwa Ritual Pataniti yaitu Bentuk dan pristiwa Ritual Pataniti yakni ketika ada musibah atau kejadian yang menimpah warga masyarakat yang ada di desa tersebut, (2).Makna dan Budaya Pataniti bagi masyarakat Jazirah ( Desa Morella dan Hila), adalah suatu keyakinan adat istiadat kepada roh-roh datuk-datuk yang ada sejak dahulu kala. percaya kepada Allah dan Muhammad, kita juga percaya kepada keramat dan roh-roh para leluhur atau kapitan karena mereka mempunyai kekuatan magic atau supranatural yang dapat membantu masyarakat yang sedang mengalami musibah. (3),Ritual Pataniti dengan Nilai-Nilai Ajaran Islam. Bagi masyarakat Jazirah ritual yang di jalankan tidak terlepas dari ajaran Islam. Pataniti disamakan dengan istighatsah, yang artinya Memanggil nama seseorang untuk meminta pertolongan. Pada hakekatnya dibolehkan selama ia seorang Muslim, Mukmin, Shalih, dan mempunya kedudukan disisi Allah.

Kata kunci: Ritual Pataniti, Budaya Masyarakat, Jazirah Leihitu

\section{PENDAHULUAN}

Masyarakat Indonesia adalah masyarakat yang majemuk, salah satu akibat dari kemajemukan tersebut adalah terdapat beraneka ragam ritual keagamaan yang di laksanakan dan di lestarikan oleh masing-masing pendukungnya. Ritual keagamaan tersebut mempunyai bentuk atau cara melestarikan serta maksud dan tujuan yang berbeda-beda antara kelompok masyarakat yang satu dengan masyarakat yang lainnya. Hal ini di sebabkan oleh adanya perbedaan lingkungan tempat tinggal, adat serta tradisi yang di wariskan secara turun temurun.

Upacara keagamaan dalam kebudayaan suku bangsa biasanya merupakan unsur kebudayaan yang paling tampak lahir. Hal ini sesuai dengan yang diungkapkan oleh Ronald Robertson, bahwa agama berisikan ajaran-ajaran mengenai kebenaran tertinggi dan mutlak tentang tingkah laku manusia dan petunjuk-petunjuk untuk hidup selamat di dunia dan di akhirat (setelah mati),yakni sebagai manusia yang bertakwa kepada Tuhannya, baradab,dan 
manusiawi yang berbeda dengan cara-cara hidup hewan atau mahluk gaib yang jahat dan berdosa. ${ }^{1}$ Namun dalam agama-agama lokal atau primitif ajaran-ajaran agama tersebut tidak di lakukan dalam bentuk tertulis tetapi dalam bentuk lisan sebagaimana terwujud dalam tradisi-tradisi atau upacara-upacara.

Sistem ritus dan upacara dalam suatu religi berwujud aktifitas dan tindakan manusia dalam melaksanakan kebaktiannya terhadap Tuhan, dewa-dewa roh nenek moyang,atau mahluk halus lain, dan dalam usahannya untuk berkomunikasi dengan Tuhan dan mahluk gaib lainnya.Ritus atau upacara religi itu biasanya berlangsung secara berulang-ulang, baik setiap hari, setiap musim atau kadang-kadang saja.

Dalam pelaksanaan upacara keagamaan masyarakat mengikutinya dengan rasa khidmat dan merasa sebagai sesuatu yang suci sehingga harus di laksanakan dengan penuh hati-hati dan bijaksana, mengingat banyaknya hal yang di anggap tabuh serta penuh dengan pantangan yang terdapat di dalamnya.Dimana mereka mengadakan barbagai kegiatan berupa pemujaan, pemudahan dan berbagai aktifitas lainnya seperti makan bersama, menari, dan menyanyi serta di lengkapi pula dengan beraneka ragam sarana dan peralatan.

Aktifitas upacara adat yang berkaitan erat dengan sistem keagamaan (religi) merupakan salah satu wujud kebudayaan yang paling sulit dirubah bila dibandingkan dengan unsur kebudayaan yang lainnya.Bahkan sejarah menunjukan bahwa aktifitas upacara adat dan lembaga-lembaga kepercayaan adalah untuk perkumpulan manusia yang paling memungkinkan untuk tetap dipertahankan.

Keadaan tersebut diatas, sangat berkaitan erat dengan kepercayaan manusia dalam berbagai kebudayaan di dunia gaib ini didiami oleh berbagai mahluk dan kekuatan yang tidak dapat dikuasai oleh manusia dengan cara-cara biasa sehingga ditakuti oleh manusia.Kepercayaan itu biasanya termasuk suatu rasa kebutuhan akan suatu bentuk komunikasi dangan tujuan untuk menangkal kejahatan, menghilangkan musibah seperti sakit, kondisi alam yang tidak bersahabat atau untuk menjamin kesejahteraan.

Dalam rangka masyarakat melaksanakan aktifitas untuk memenuhi kebutuhan hidup biasanya dipangaruhi oleh adanya kepercayaan dan nilai-nilai yang dianutnya seperti nilai budaya, hukum, norma-norma maupun aturanaturan khusus lainnya.

Demikian pula bagi masyarakat di Jazirah Leihitu dalam memenuhi kebutuhannya terutama pemenuhan kebutuhan akan keselamatan dan ketentraman guna mempertahankan kelangsungan hidupnya yang dipenuhi oleh kepercayaan dan nilai-nilai yang terdapat dalam tradisi keagamaan yang disebut Pataniti. Anggapan masyarakat di Jazirah Leihitu merupakan suatu bentuk ritual keagamaan yang bersifat sakral (suci ) yakni suatu kekuatan simbolis atau tindakan sekaligus sebagai wujud dari ekspresi jiwa mereka dalam menjalin hubungan vertikal dengan penghuni dunia gaib.

$$
\text { Penyelenggaraan ritual Pataniti }
$$
mempunyai kandungan nilai yang penting bagi kehidupan masyarakat pendukungnya, karena dianggap sebagai suatu kearifan lokal dan nilai budaya yang dapat membawa keselamatan diantara sekian banyak unsur budaya dan bentuk kearifan local yang ada pada masyarakat. Pataniti saat ini masih tetap dilaksanakan oleh masyarakat di Jazirah Leihitu Kabupaten Maluku Tengah.

Dari uraian di atas, penulis tertarik untuk meneliti lebih lanjut tentang makna dari ritual 
tersebut bagi masyarakat. Mengapa sampai saat ini masyarakat masih tetap mempertahankan tradisi ini, dengan judul "Ritual Pataniti (Studi Budaya Masyarakat di Jazirah Leihitu Kabupaten Maluku Tengah)”,

\section{PROSES, BENTUK DAN PERESTIWA RITUAL PATANITI}

Adapun Bentuk dan pristiwa Ritual Pataniti yakni ketika ada musibah atau kejadian yang menimpah warga masyarakat yang ada di desa tersebut, hal ini berdasarkan keterangan yang diberikan oleh salah seoran Toko Adat Negeri Morella, ia menjelaskan bahwa :

Budaya Pataniti ini akan berlansung ketika ada sebab atau kejadian yang menimpa, di umpamakan ketika terjadi bencana dalam perjalanan, baik itu di laut ataupun daratan. Selain itu Pataniti ini juga dilakansakan pada saat prosesi adat seperti pelantikan Raja, serta budaya-budaya yang lainnya. ${ }^{2}$

Untuk melaksanakan Proses adat ini maka diperlukan syarat-syarata yang harus di laksanakan, adapun syarat-syarat untuk melakasakan Pataniti adalah sebagai berikut :

1. Ayam hitam 1 ekor

2. Telur ayam Kampung 3 Butir

3. Nasi Kuning

4. Tabako (Tembakau)

5. Daun Siri dan Buah Pinang

6. Kain Beran (Kain Yang berwarna Merah)

Seteleh semuah bahan ini terkumpul, maka barang tersebut di sajikan di tempat Pamali (yang dianggap ada penghuninya/Roh Leluhur).

Hal yang sama terjadai pula di Negeri Hila, namaun proses pelaksanaannya berbeda. Masyarakat Negeri Hila selalu melakukan sebuah proses ritual pengambilan Pataniti bila ada masyarakat yang mengalami musibah, maka mereka melakukan ritual pengambilan Pataniti.

\footnotetext{
${ }^{2}$ Juairia Ulath Wawancara "Toko Adat Negeri Morella, 25 Oktober 2016
}

Adapun tempat atau ritus-ritus dan wilayah yang tertentu pengambilan Pataniti yaitu Batu Pamali, Waitomo, Titipolo, Wakahili, Tahoku, Parang sana, Kuburan, Tuguh. sesajian yang di sajikan oleh roh para leluhur, untuk memanggil pulang roh si penderita tadi. Yang pertama kita mengirim doa di rumah orang yang sedang sakit, yang kedua kita mengirim doa di batu pamali, untuk meminta bantuan kepada Allah, dan roh para leluhur. Adapun yang harus kita persiapkan atau sebagai syarat-syaratnya :

1. Ayam hitam 1 ekor atau kasuari

2. Damar secukupnya (gunanya di baker di atas batu pamali)

3. Kamanyiang secukupnya (gunanya untuk memanggil roh para leluhur)

4. kain sarung (kain gendong) berwarna merah gunanya untuk menggendong roh si penderita

Setelah semua bahan sudah di kumpulakn maka Pemimpin adat memimpin ritual pengambilan Pataniti. Yang membawa kain sarung itu dan langsung beliau melakukan ritual dengan berteriak selama tiga kali di batu pamali dengan menyebut nama latu Roh Alain dengan bahasa Hila yaitu: Ismail ee Kululaoi Nilahat Leke Lem l'akah retina I lelaha Karnmlny.

Artinya, ( ismail e turung kamari pulang ikut ose punya tikar bantal dirumah) berteriak selama tiga kali, dan sesudah itu, di setiap tempat yang ada penghuninya harus berteriak dan memanggil roh yang sedang kerasukan sebanyak tiga kali agar dapat di kembalikan ke Negeri dengan keadaan sehat. $^{3}$

\section{MAKNA BUDAYA PATANITI}

Pemahaman Pataniti adalah suatu keyakinan adat istiadat kepada roh-roh datukdatuk yang ada sejak dahulu kala. Kami masyarakat Desa Hila percaya kepada Allah dan Muhammad, kita juga percaya kepada keramat

${ }^{3}$ Hasanudin Mony. Masyarakat Desa Hila. Tokoh yang Memimpin Ritual.” wawancara”. 23 Oktober 2016 
dan roh-roh para leluhur atau kapitan karena mereka mempunyai kekuatan magic atau supranatural yang dapat membantu masyarakat yang sedang mengalami musibah. ${ }^{4}$

Menurut masyarakat Desa Hila, Pemahaman tentang Pataniti adalah suatu kepercayaan atau adat yang diyakinkan sejak dulu yang sudah menjadi sebuah ritual yang mempunyai kekuatan transendental atau supranatural yang berada di luar kemampuan dan pandangan pancaindra manusia. Pataniti adalah sebuah keyakinan masyarakat Desa Hila yang dipercayai sebagai suatu proses keyakinan untuk membentu masyarakat."

Demikian halnya yang terjadi di Negeri Morella bagi mereka Pataniti merupakan tradisi yang ada sejak dahulu, hal ini telah mendarah daging dan tidak bisa dilepas pisahkan dari masyarakat Negeri Morella. Dilihat dari kehidupan keseharian masyarakat Negeri Morella, bagi mereka pataniti merupakan sebuah perwujudan kepribadian alami yang dimaknai sebagai sebuah kekuatan yang mampu memberikan pertolongan bagi mereka.

Terkait dengan penjelasan di atas, salah seorang pemuda Negeri Morella menjelaskan bahawa

"Pataniti merupakan sebuah tindakan atau perilaku yang sejak dulu dan bukan saja menjadi budaya bagi kami, pataniti ini sudah mendarah daging bagi kami semenjak lahirnya seorang bai, dan ini tidak bisa dilepas pisahkan dari kami. ${ }^{6}$

Pandangan masyarakat terhadap Pataniti ini didasarkan pada anggapan sebagian masyarakat Negeri Hila-Morella bahwa Pataniti adalah jelmaan dari roh para leluhur atau roh suci yang dapat membantu masyarakat Negeri kedua Negeri ini.

\footnotetext{
${ }^{4}$ Mama Dewi Launuru. Masyarakat Desa Hila, "wawancara ", tgl 15 Oktober 2016

${ }^{5}$ Achmad Selang.Tokoh Adat. Masyarakat Desa Hila" Wawancara ",tgl 18 Oktober 2016
}

\section{RITUAL PATANITI DENGAN NILAI- NILAI AJARAN ISLAM}

Pataniti Bagi masyatakt Morella bukanlah hal yang tabu, bagi masyarakat morella pataniti meruapakan kebiasan yang sudah membudaya dan tidak bisa dilepas pisahkan. Bagi mereka ritual yang di jalankan tidak terlepas dari ajaran Islam hal ini berdasarkan keterangan yang disampaikan oleh salah seorang toko Pemuda "Ilham Leikwa" Ia menjelaskan Bahwa

Pataniti jika di dalam bahasa arab adalah istighatsah, yang artinya Memanggil nama seseorang untuk meminta pertolongan. Bagi sebagian kelompok muslimin hal ini langsung divonis syirik. Namun vonis mereka hanyalah karena kedangkalan pemahamannya terhadap Syariah Islam. Pada hakekatnya memanggil nama seseorang untuk meminta pertolongan adalah hal yang dibolehkan selama ia seorang Muslim, Mukmin, Shalih, dan mempunya kedudukan disisi Allah Swt, baik ia masih hidup atau telah wafat. Karena bila seseorang mengatakan ada perbedaan dalam kehidupan dan kematian atas manfaat dan mudharat, maka justru dirisaukan ia telah terjebak dalam kemusyrikan yang nyata, ${ }^{7}$

Penjelasan di atas dapat di jelaskan sebagaimana telah difirmankan Allah Swt dalam surat Al-Baqarah ayat 154 :

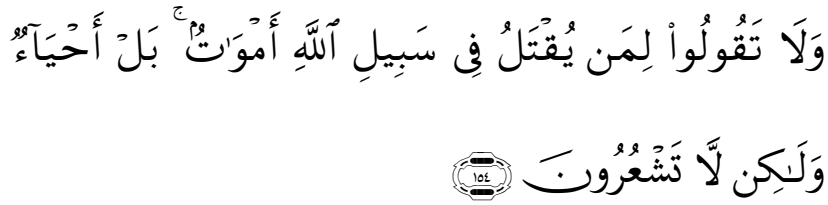

Terjemahnya:

Dan janganlah kamu mengatakan terhadap orang-orang yang gugur di jalan Allah, (bahwa mereka itu) mati; bahkan (sebenarnya) mereka

${ }^{6}$ Badarih Mony. Masyarakat Negeri Morella , "Wawaneara" Pada tannggal 21 Oktober 2016

${ }^{7}$ Wawancara Ilham Leikawa (Toko Pemuda Negeri Morella) Negeri Morella 25 Oktober 2016 
itu hidup, tetapi kamu tidak menyadarinya (Qur'an Al-baqarah ayat 154).

Ayat di atas menjelaskan hawa hal yang ghaib itu sesungguhnya ada dan yang ghaib itu semua dari Allah Swt, maka dari itu kita selaku umat islam wajib mempercayainya, Sebab seluruh manfaat dan mudharat berasal dari Allah Swt, maka kehidupan dan kematian tak bisa membatasi manfaat dan mudharatkecuali dengan izin Allah Swt.

Selain itu, Ilham Leikawa juga menjelaskan, Ketika seseorang berkata bahwa orang mati tak bisa memberi manfaat, dan orang hidup bisa memberi manfaat, maka dikhawatirkan telah jatuh dalam kekufuran karena menganggap kehidupan adalah sumber manfaat dan kematian adalah mustahilnya manfaat, padahal manfaat dan mudharat berasal dari Allah Swt. Kekuasaan Allah Swt tidak bisa dibatasai dengan kehidupan atau kematian. Sama halnya ketika seorang berkata bahwa hanya dokterlah yang bisa menyembuhkan penyakit dan tak mungkin kesembuhan datang dari selain dokter. Maka ia telah membatasi kodrat Allah Swt untuk memberikan kesembuhan, yang bisa saja lewat dokter, juga tak mustahil lewat orangorang kita yang biasa diistilahkan dengan kata "pa'meu" (tabib) bahkan bisa sembuh dengan sendirinya semuanya atas izin Allah Swt, sebagai contoh: orang yang kena pa'muwat atau santet bisakah disembuhkan dengan dokter? orang pasapela (Kerasukan Roh Jahat, atau Iblis) bisakah dengan dokter, yang kena Upas (penyakit aneh yang datang secara spontan) apakah dengan ilmu kedokteran langsung sembuh dengan cepatnya?

Terkadang kita tidak menyadari bahwa kita lebih banyak mengambil manfaat dalam kehiduan ini dari mereka yang telah meninggal daripada pada yang masih hidup. Sungguh peradaban manusia, tuntunan ibadah, tuntunan kehidupan, modernisasi dan lain sebagainya, para pelopornya telah wafat. Kita masih terus mengambil manfaat dari mereka, baik muslim maupun yang non-muslim, sepert teori Einstein dan teori-teori lainnya atau hal yang paling dekat jika tidak ada perjuangan yang gigih dari leluhur kita, saya rasa sampai saat ini kita bisa saja sudah bukan muslim atau sebagainya naa'udzubillaahi mindzaalik. Kita masih mengambil manfaat dari yang mati hingga kini, berupa ilmu, kekuatan, jabatan, atau perjuangan mereka. Cuma bedanya dengan para shalihin, para wali, dan muqarrabin kita mengambil manfaat dari iman, amal shalih, dan ketaatan mereka kepada Allah Swt.

Rasul SAW membolehkan istigatsah atau pataniti, sebagaimana sabda beliau SAW, "Sungguh matahari mendekat dihari kiamat hingga keringat sampai setengah telinga, dan sementara dalam keadaan itu mereka beristigatsah (memanggil nama untuk minta tolong) kepada Adam, lalu kepada Musa, dan juga Isa. Kesemuanya tak mampuh berbuat apaapa lalu mereka ber-istigatsah kepada Muhammad SAW," (shahih Bukhari hadits Ni.1405) Hadits serupa terdapat juga pada Shahih Muslim hadits No. 194, Shahih Bukhari No. 1362, 3182, 4435. Dan masih banyak lagi Hadits-hadits shahih yang menunujukkan ummat manusia ber-istigatsah pada para Nabi dan Rasul. Bahkan pada Adam, "Wahai Adam, sungguh engkau adalah ayah dari semua manusia (hingga selesai ucapan itu). Adam berkata, "Diriku diriku, pergilah pada selainku," Hingga akhirnya mereka beristigatsah memanggil-manggil Muhammad SAW, dan Nabi SAW sendiri yang menceritakan ini dalam hadits bukan dongeng. Hal ini menunjukkan bahwa beliau tak mengharamkan istigatsah.

Hadits sangat jelas merupakan rujukan bagi istigatsah. Rasul SAW menceritakan orangorang ber-istigatsah kepada manusia, dan Rasul SAW tak mengatakan syirik. Namun istigatsah 
atau pataniti di hari kiamat hanya untuk Sayyidina Muhammad SAW.

Diriwayatkan bahwa seseorang dihadapan Ibnu Abbas RA keram kakinya, lalu Ibnu Abbas berkata "Sebut nama orang yang paling kau cintai!" Aorang itu berkata dengan suara keras, "Muhammad!" maka dalam sekejap sembuh keramnya (Diriwayatkan oleh Imam Tabrani dengan sanad Hasan. Juga diriwayatkan oleh Imam Nawawi dalam al-Adzkar). Dalam riwayat ini tidak dikatakan musyrik orang yang memanggil nama seseorang saat mendapatkan8

Sementara dalam pandangan masyarakat Negeri Hila, Ritual yang sering dilakukan oleh masyarakat pada umumnya tidak terelepas dari ajaran islam hal ini berdasarkan hasil wawancara bersama salah seorang toko Agama Negeri Hila Ibrahim Launuru, ia menjelaskan bawa ketika ritual dilakukan selalu mengawali dengan kata bismillah, kemudian dilafaskan dengan niat yang sama pula dalam bahasa budaya agar tidak rentan oleh apa yang dinamakan dengan syirik Artinya dalam setiap perkatan yang dilafatskan itu adalah doa dengan niat yang baik kemudian dikhiri pula dengan doa

Aqidah atau tauhid merupakan pokok perintah tentang keesaan Allah, bahwa tidak ada yang patut disembah kecuali Allah Swt dengan segala sifat dan keagungannya. Ada sebagian ulama yang membagi tauhid menjadi dua bagian saja dengan menggabungkan Tauhid Asma' wa Shifat pada Tauhid Rububiyah. Dan tidak ada masalah dalam hal ini, karena yang dimaksud oleh dua macam pembagian ini sudah jelas. Adapun yang lain membagi Tauhid menjadi tiga, yaitu: ${ }^{9}$

${ }^{8}$ http://Tifa

tomasiwa.blogspot.co.id/2011/03/apakah-pataniti-itusyirik.html.id
1) Tauhid Rububiyah ialah mengimani bahwa Allah Swt adalah pencipta segala sesuatu dan mengurus kesemuanya dan tidak ada sekutu bagi-Nya dalam hal tersebut.

2) Tauhid Uluhiyah ialah mengimani bahwa Allah Swt Dialah yang berhak untuk disembah dengan haq, tidak ada sekutu bagi-Nya dalam hal tersebut. Artinya tidak ada yang pantas disembah dengan haq kecuali Allah Swt. Maka, segala bentuk ibadah seperti shalat, puasa dan yang lainnya, wajib dilaksanakan hanya untuk Allah semata. Tidak boleh ada satu bentuk ibadah pun yang ditujukan kepada selain Allah Subhanahu wa Ta'ala.

3) Tauhid Asma'waShifat ialah mengimani semua apa yang disebutkan dalam AlQur'anul Karim dan Hadits-hadits shahih tentang nama-nama Allah Swt dan sifatsifat-Nya. Lalu menetapkan itu semua untuk Allah tanpa 'tahrif' (mengubah), tanpa ta'thil (meniadakan), takyif (menanyakan bagaimana caranya), dan tanpa tamstil (penyerupaan), sesuai dengan firman Allah Subhanahu wa Ta'ala:

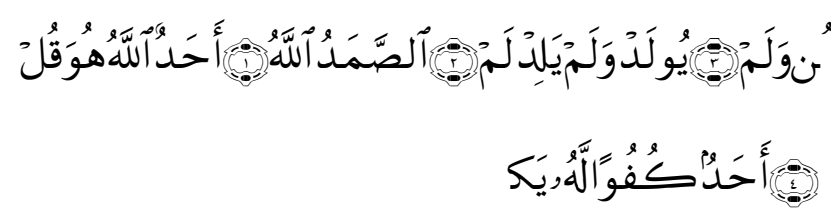

Terjemahnya:

"Katakanlah (Muhammad), "Dialah Allah, Yang Maha Esa. Allah tempat meminta segala sesuatu. Allah tidak beranak dan tidak pula diperanakkan.Dan tidak ada sesuatu yang setara dengan Dia". (QS. [112] Al-Ikhlas: ayat; 1-4). ${ }^{10}$

${ }^{9}$ Buku-buku islam.yayasan as-sofwah, et. Free html;http//; www.as-sofwah.or.id.Diakses pada tanggal 5 Oktober 2016.

${ }^{10}$ Al-Quran dan Terjemahannya, (Surakarta: Pustaka Al-Hanan, tt), hlm. 604. 
Aqidah atau tauhid dalam islam mengajarkan kita yakin kepada keesaan Tuhan, tauhid yang dimulai dengan dua kalimat syahadat: "Aku bersaksi tiada Tuhan yang berhak disembah selain Allah, dan aku bersaksi bahwa sesungguhnya Nabi Muhammad adalah Rasul-Nya”. Dan firman Allah Swt:
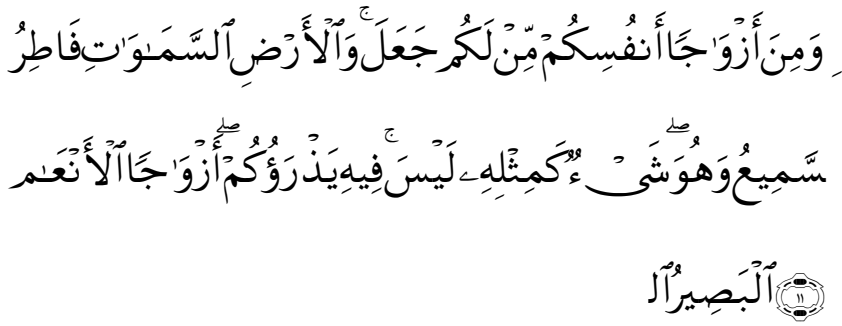

Terjemahnya:

"Allah pencipta langit dan bumi. Dia menjadikan bagi kamu pasangan-pasangan dari jenismu sendiri, dan dari jenis hewan ternak terdapat pasangannya juga, dijadikannya kamu berkembang biak dengan jalan itu. Tidak ada sesuatu pun yang serupa dengan Dia. Dan Dialah Yang Maha Mendengar lagi Maha Melihat." (QS. [42] Asy-Syura: ayat; 11). ${ }^{11}$

Secara garis besar keyakinan, iman atau aqidah islam mencakup enam dasar ketetapan yang mesti dijalankan oleh setiap pribadi muslim, sebagai berikut:

1. Iman kepada Allah Swt dengan namanama-Nya yang mulia (99 Al-ashma Alhusnah), sifat-sifat-Nya yang sempurna, dan bukti-bukti wajib sifat keagunganNya.

2. Iman kepada yang ada di balik alam semesta yang tak dapat dilihat wujudnya dengan panca indra, yaitu percaya dengan adanya Malaikat dan kekuatan-kekuatan yang jahat seperti jin dan setan. Konteks percaya terhadap jin dan setan ini sebagai pemberitahuan akan pengakuan bahwa selain manusia, ada mkhluk ciptaan Allah yang lain, dan konteks percaya ini bukan dalam bentuk keharusan ibadah atau penyembahan selain Allah.

3. Iman kepada kitab-kitab Allah yang telah diturunkan kepada Nabi Muhammad (Alqur'an) dan kitab-kitab yang diturunkan sebelumnya, yaitu Taurat, Zabur, dan Injil. Meskipun dewasa ini sulit pula menemukan wujud asli kitab-kitab tersebut sebagaimana yang diharuskan dalam Alqur'an.

4. Iman kepada nabi-nabi serta Rasul Allah Swt (25 nabi) sebagai pembimbing umat pada zamannya.

5. Iman kepada hari kiamat atau hari akhir, termasuk iman kepada kebangkitan dari kubur, adanya Shirat, Ya'umul Mahsyar, Ya'umul Hishab, Ya'umul Mizhan, Surga dan Neraka.

6. Iman kepada ketetapan Allah terhadap segala sesuatu berupa takdir (qadha dan qadar).

Persoalan tauhid atau akidah merupakan hal yang paling mendasar dalam membentuk keimanan seseorang, sebagai umat muslim diharuskan beribadah hanya kepada Allah Swt dalam memurnikan ketaatan kepada-Nya dalam menjalankan agama yang benar, hal ini sebagaimana terdapat dalam firman-Nya:

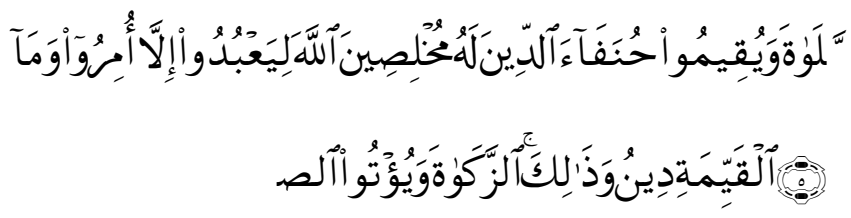

Terjemahnya:

Padahal mereka hanya diperintah menyembah Allah, dengan Ikhlas mentaati-Nya semata-mata karena (menjalankan) agama, dan juga agar melaksanakan Shalat dan menunaiakan Zakat;

\footnotetext{
${ }^{11}$ Ibid., hlm. 484.
} 
dan yang demikian itulah agama yang lurus (benar). (QS Al-Bayyinah [98]: ayat; 5). ${ }^{12}$

Dengan demikian kewajiban dan perintah memurnikan ketaatan dalam beribadah hanya kepada Allah saja, jika beribadah kepada makhluk lain maka dianggap syirik (menyekutukan) Allah dengan makhluk lain. Terkait dengan penyekutuan (Syirik) ini oleh para ulama dibagi menjadi tiga bagian, sebagai berikut: ${ }^{13}$

1) Syirik besar (akbar) akan menghapuskan pahala amal dan akan mengekalkan pelakunya di dalam Neraka. Seperti yang difirmankan oleh Allah Swt:

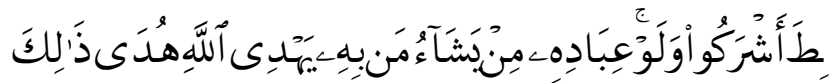

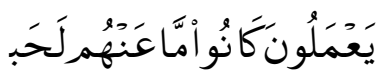

Terjemahnya:

"Dan kalau mereka melakukan syirik (menyekutukan Allah dengan sesuatu), pasti akan gugur dari mereka (pahala) apa yang mereka lakukan." (Al-An'am:88).

Allah Subhanahu wa Ta'ala berfirman:
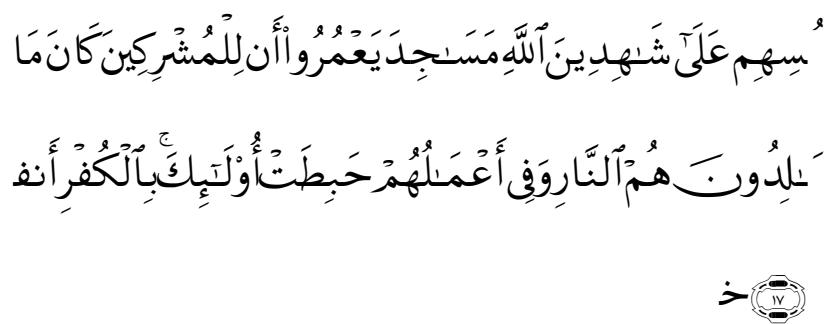

Terjemahnya:

"Tidaklah pantas orang-orang musyrik itu memakmurkan masjid-masjid Allah, sedang mereka mengakui bahwa mereka sendiri kafir Itulah orang-orang yang sia-sia pekerjaannya, dan mereka kekal di dalam Neraka." (QS.AtTaubah:17). ${ }^{14}$

\footnotetext{
${ }^{12}$ Al-Quran dan Terjemahannya, (Surakarta: Pustaka Al-Hanan, tt), hlm. 598.

${ }^{13}$ Op. Cit.
}

Dan barangsiapa yang mati dalam keadaan melakukan syirik akbar, maka dia tidak akan diampuni, dan Surga diharamkan baginya. Allah Swt berfirman:

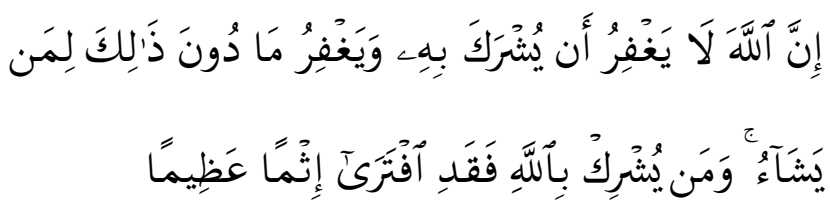

Terjemahnya:

Sesungguhnya Allah tidak akan mengampuni dosa syirik, dan Dia mengampuni segala dosa yang selain dari (syirik) itu, bagi siapa yang dikehendaki-Nya. Barangsiapa yang mempersekutukan Allah, Maka sungguh ia telah berbuat dosa yang besar.." (QS. [4] An-Nisa: ayat; 48). ${ }^{15}$

Di dalam ayat lain Allah Subhanahu wa Ta'ala juga berfirman:

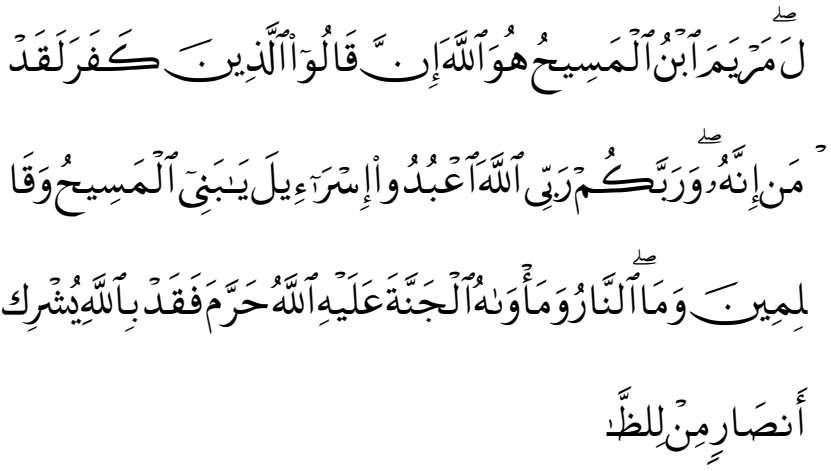

Terjemahnya:

"Sesungguhnya orang yang mempersekutukan (sesuatu dengan) Allah, maka pasti Allah mengharamkan kepadanya Surga, dan tempatnya ialah Neraka, dan tidaklah ada bagi orang-orang zhalim itu seorang penolong pun." (QS.[5] Al-Maidah: ayat; 72). ${ }^{16}$

Yang termasuk syirik akbar, di antaranya adalah berdo'a (meminta) kepada orang mati dan patung (berhala), mohon perlindungan kepada mereka, juga bernadzar dan berkorban

\footnotetext{
${ }^{14} \mathrm{Op}$. Cit.

${ }^{15}$ Ibid.

${ }^{16}$ Ibid.
} 
(menyembelih binatang) untuk mereka dan lain sebagainya.

2) Syirik kecil (Ashghar) ialah beberapa tindakan yang sudah jelas disebutkan dalam nash-nash Al-Qur'an dan Sunnah sebagai syirik, tetapi tidak termasuk jenis syirik besar. Contohnya adalah riya' (ingin dilihat orang) dalam beramal, bersumpah tidak dengan nama Allah dan mengatakan (Sesuatu yang dikehen-daki oleh Allah dan dikehendaki oleh si fulan) dan lain sebagainya. Rasulullah sawbersabda:

"Sesuatu yang paling aku takuti terhadap kalian adalah syirik kecil.Lalu beliau ditanya syirik kecil itu.Beliau menjawab: riya'."(HR. Imam Ahmad, Ath-Thabrany, Al-Baihaqi dari Mahmud bin Labid Al-Anshari radhiallahu 'anhu dengan sebuah sanad yang baik, dan diriwayatkan oleh Ath-Thabranydengan beberapa sanad yang baik dari Mahmud bin Labid-- dari Rafi' bin Khudaij dari Nabi shallallahu 'alaihi wa sallam).

Rasulullah shallallahu 'alaihi wa sallam juga bersabda:

"Barangsiapa yang bersumpah dengan sesuatu selain Allah- maka dia telah menyekutukan (Allah)."(HR. Ahmad dengan sanad yang shahih).

Hadits Umar bin Khaththab radhiallahu 'anhu dan diriwayatkan pula oleh Abu Daud dan At-Tirmidzi dengan sanad yang shahih dan hadits Ibnu Umar radhiallahu'anhu dari Nabi shallallahu 'alaihi wa sallam, bahwasanya beliau bersabda:

"Barangsiapa yang bersumpah dengan (menyebut nama) selain Allah, maka dia telah kafir atau syirik."

Rasulullah shallallahu 'alaihi wa sallam bersabda:

"Janganlah kalian mengatakan: ('Atas kehendak Allah dan kehendak si fulan'), tapi katakanlah:
('Atas kehendak Allah kemudian atas kehendak si fulan')." (HR. Abu Daud dengan sanad yang shahih dari Hudzaifah bin Al-Yaman radhiallahu 'anhu).

Syirik kecil ini tidak menyebabkan seseorang keluar dari Islam serta tidak memastikan kekalnya seseorang di dalam Neraka, tetapi menghilangkan kesempurnaan tauhid yang semestinya.

3) Syirik Samar (khofi) ini didasarkan pada sabda Rasulullah saw, yang mana beliau bertanya kepada para sahabat:

"Bagaimana sekiranya aku beritahu kalian tentang sesuatu yang lebih aku takuti (terjadi) pada kalian daripada Al-Masih Ad-Dajjal? Mereka menjawab: Ya, wahai Rasulullah! Rasulullah bersabda: "Syirik yang samar (contohnya), sese-orang berdiri lalu dia melakukan shalat maka dia perbagus shalatnya karena dia melihat ada orang lain yang memperhatikan kepadanya." (HR.Imam Ahmad dalam Musnadnya dari Abi Said Al-Khudri radhiallahu 'anhu).

Bisa juga syirik itu dibagi menjadi dua bagian saja.Syirik besar dan syirik kecil.Adapun syirik khofi, bisa masuk dalam dua jenis syirik tadi.Bisa terjadi pada syirik besar, seperti syiriknya orang-orang munafik. Karena mereka itu menyembunyikan keyakinan sesat mereka dan berpura-pura masuk Islam dengan dasar riya' dan khawatir akan keselamatan diri mereka. Bisa juga terjadi pada syirik kecil seperti yang disebutkan dalam hadits Mahmud bin Labid AlAnshari yang terdahulu dan hadits Abu Said yang tersebut di atas.

Sementara itu, disyariatkan bagi kaum pria untuk berziarah kubur dari waktu ke waktu. Tujuannya untuk mendo'akan yang mati, memohonkan rahmat untuk mereka, juga untuk mengingatkan akan kematian dan apa yang ada setelah itu. Karena Nabi saw bersabda: 
"Ziarahilah kubur itu, sesungguhnya dia akan mengingatkan kalian tentang alam akhirat."(Hadits dikeluarkan oleh Imam Muslim dalam Kitab Shahihnya).

Rasulullah shallallahu 'alaihi wa sallam juga mengajarkan kepada para sahabatnya apabila mereka berziarah kubur untuk mengucapkan:

"Keselamatan untuk kalian wahai ahli kubur dari kaum mu'minin dan muslimin, dan sesungguhnya kami Insya Allah akan menyusul kalian.Kami memohon kepada Allah keselamatan untuk kami dan untuk kalian.Semoga Allah merahmati orang-orang yang mati lebih dahulu dari kami dan juga orang-orang yang akan mati belakangan."

Adapun kaum wanita, maka dia tidak boleh melakukan ziarah kubur, karena Rasulullah saw melaknat kaum wanita yang menziarahi kubur. Alasannya adalah karena takut terjadi fitnah dan tidak mampu menahan kesabaran. Begitu pula, mereka tidak boleh ikut mengantar jenazah sampai ke kuburan. Karena Rasulullah saw juga melarang hal tersebut. Akan tetapi, menshalatkan jenazah baik di masjid maupun di tempat lain dibolehkan untuk pria dan wanita semuanya.

Pelaksanaan ritual tradisi Pataniti pada masyarakat Negeri Morella-Hila merupakan tradisi yang diwarisi oleh leluhur secara turuntemurun, dilakukan sebagai bentuk penghormatan kepada arwah para leluhurnya. Adapun pelaksanaan tradisi Pataniti berupa sesajian yang disajikan sebagai makanan buat leluhur (memberi makan leluhur), bertujuan untuk menolong dan membantu ketika ada yang mendapatkan musibah.

Dengan demikian, maka di dalam pelaksanaan ritual tradisi Pataniti ini mengandung dua unsur perbuatan manusia, unsur pertama; menunjukan bagaimana masyarakat Morella-Hila menjalankan tradisi
Pataniti sebagai bentuk amanah sekaligus warisan yang diwarisi dan diwasiatkan oleh leluhurnya. Unsur yang kedua; bertujuan untuk memperoleh sesuatu dari perbuatannya, berupa ketentraman, kedamaian, terhindar dari berbagai malapetaka, dan bencana yang menimpa.

Pelaksanaan tradisi Pataniti dilakukan oleh tokoh adat, dan tokoh agama atau orangorang yang dianggap berpengetahuan tentang tradisi itu (Ahlinya), pelaksanaan tradisi ini bukan atas kehendaknya, melaikan atas kehendak leluhur yang telah diwasiatkan, diwariskan, dan diamanahkan kepada anak cucunya, sehingga diantara mereka ada hubungan, bagi mereka yang melaksanakan tradisi ini dikenai urusan yang bersifat amanah, "Sesungguhnya Allah mewajibkan kamu menunaikan amanah itu sesuai ahlinya(QS. [4]: An-Nisa ayat: 48)". Biasanya kebiasaan dan perbuatan leluhur merupakan suatu perbuatan yang telah terjadi dimasa lampau, kebiasaan ini sebagai wujud aktualisasi keyakinan leluhur terhadap berbagai fenoma yang dihadapi kala itu. Sementara itu, bagi masyarakat yang hidup dizaman ini melakukan segala sesutu untuk keberlangsungan kehidupannya.

Sebagaimana telah diuraikan tentang Aqidah atau tauhid di atas, jika suatu perbuatan dalam konteks ibadah tertuju kepada selaian Allah maka dianggap telah menyekutukan Allah, sehingga perbuatan itu bisa pula dianggap syirik. Sementara itu, suatu perbuatan yang dilakukan atas hubungan muamalah dan bukan merupakan perbuatan yang bersifat ibadah pokok, dapat dilakukan. Pelaksanaan tradisi Pataniti dilakukan sebagai bentuk penghormatan kepada leluhurnya dalam menjalankan amanah (warisan) leluhur. Pada sisi yang lain pelaksanaan tradisi Pataniti bertujuan memeberimakan (sesajian) kepada arwah para leluhur, sekaligus mememinta dijauhkan dari berbagai penyakit 
Malapetaka/Musibah yang menimlah masyarakat kedua negeri tersebut.

Dalam islam, Mengunjungi atau berjiarah ke makam para leluhur, dan berdoa untuk pengampunan Allah atas dosa-dosa mereka (leluhur) dan berdoa kepada Allah untuk keselamatan dan ketabahan mereka yang masih hidup, dibolehkan sebagai mana bersabda Rasulullah:

"Ziarahilah kubur itu, sesungguhnya dia akan mengingatkan kalian tentang alam akhirat."(Hadits dikeluarkan oleh Imam Muslim dalam Kitab Shahihnya).

Rasulullah saw juga mengajarkan kepada para sahabatnya apabila mereka berziarah kubur untuk mengucapkan:

"Keselamatan untuk kalian wahai ahli kubur dari kaum mu'minin dan muslimin, dan sesungguhnya kami Insya Allah akan menyusul kalian.Kami memohon kepada Allah keselamatan untuk kami dan untuk kalian.Semoga Allah merahmati orang-orang yang mati lebih dahulu dari kami dan juga orang-orang yang akan mati belakangan."

Dalam konteks ini untuk mengingat akan adanya hari akhir atau kehidupan sesudah kematian (kiamat) yang merupakan salah satu perintah diutusnya Rasul, tercantum dalam risalah kerasulan dan dengan tegas dinyatakan Allah sebagai berita yang besar, sebagai mana terdapat dalam Al-qur'an Surah Al- Naba. Perintah berjiarah ke kubur atau makam para leluhur atau orang mati dengan mendoakan mereka kepada Allah, dan bukan berdoa kepada mereka, mengandung makna relevansi dengan anak yang shaleh yang mendoakannya (amalan orang yang meninggal) tidak terputus karena meninggalkan anak yang shaleh (generasi yang taat, patuh, jujur, berakhlak mulia, amanah, dan berbakti kepada orang tua), meskipun pada konteks ini masih terdapat perbadaan pandangan dari para ulama.
Berdasarkan pada penyajian data hasil penelitian dan analisis terhadap permasalahan sebagaimana disajikan di atas, pelaksanaan tradisi Pataniti pada masyarakat Negeri Morella dan Hila merupakan suatu bentuk aktualisasi pola kebiasaan yang diwarisi dari kebiasaan leluhurnya secara turun temurun. Pola kebiasaan yang telah melekat dan diterima oleh masyarakatnya secara umum merupakan suatu bentuk tradisi atau adat kebiasaan yang bersifat mengikat dan mengatur tingkah laku masyarakatnya.

Tradisi dan adat kebiasaan yang dimiliki oleh masyarakat Negeri Morella dan Hila hanya berlaku bagi masyarakatnya. Pelaksanaan tradisi Pataniti ini masih bersifat tertutup, dan khusus dilakukan oleh masyarakat Negeri Morella dan Hila. Pada pelaksanaan ritual tradisi Pataniti bukan merupakan suatu bentuk ritual ibadah pokok yang merupakan perintah dari suatu agama, karena dalam suatu agama niscaya tidak ditemukan tradisi Pataniti. Hanya saja sebagian besar warga yang melaksanakan tradisi ini menganut agama islam, sehingga setiap pribadi yang meyakini dan mengimani suatu ajaran agama, khususnya agama islam, senantiasa meletakkan setiap perbuatan berdasarkan pada ajaran islam.

Dari sinilah memungkinkan adanya pendekatan nilai agama pada tata cara pelaksanaan tradisi ini. Dengan demikian, pada satu sisi tradisi Pataniti mesti dilihat sebagai bentuk pelaksanaan ritual adat (urf) yang merupakan nilai adat yang mengikat ( $\mathrm{Al}$ adatu muhkamat) warga Negeri Morella dan Hila sebagai bentuk aktualisasi nilai kepercayaannya. Dan disisi lain tradisi Pataniti hanya merupakan suatu pola kebiasaan hidup yang dilakukan oleh masyarakatnya sebagai bentuk hubungan sosial, dalam arti telah menjadi pola kebiasaan yang berlaku secara umum bagi masyarakatnya. 


\section{KESIMPULAN}

Berdasarkan uraian pada hasil dan pembahasan, maka peneliti dapatl menarik beberapa simpulan yang signifikan terkait dengan Ritual Pataniti, sebagai berikut

1. Pataniti merupakan suatu bentuk ritual keagamaan yang bersifat sakral (suci ) yakni suatu kekuatan simbolis atau tindakan sekaligus sebagai wujud dari ekspresi jiwa mereka dalam menjalin hubungan vertikal dengan penghuni dunia ghaib. Pataniti mempunyai kandungan nilai yang penting bagi kehidupan masyarakat, dalam pemenuhan kebutuhan akan keselamatan dan ketentraman guna mempertahankan kelangsungan hidupnya yang dipenuhi oleh kepercayaan dan nilai-nilai yang terdapat dalam tradisi keagamaan

2. Bentuk dan pristiwa Ritual Pataniti adalah ketika ada musibah atau kejadian yang menimpah warga masyarakat yang ada di desa tersebut, hal ini pun terjadi pada dua negeri adat antara Desa Morella dan Desa Hila Jazirah Leihitu Kabupaten Maluku Tengah.

Makna budaya pataniti adalah suatu keyakinan adat istiadat kepada roh-roh datuk-datuk yang ada sejak dahulu kala. Pada masyarakat Desa Morella dan Desa Hila percaya kepada Allah dan Muhammad, kita juga percaya kepada keramat dan rohroh para leluhur atau kapitan karena mereka mempunyai kekuatan magic atau supranatural yang dapat membantu masyarakat yang sedang mengalami musibah.

3. Ritual pataniti dengan nilai-nilai ajaran Islam. Pataniti jika di dalam bahasa arab adalah istighatsah, yang artinya Memanggil nama seseorang untuk meminta pertolongan. Pada hakekatnya memanggil nama seseorang untuk meminta pertolongan adalah hal yang dibolehkan selama ia seorang Muslim, Mukmin, Shalih, dan mempunyaai kedudukan disisi Allah Swt, baik ia masih hidup atau telah wafat. Karena bila seseorang mengatakan ada perbedaan dalam kehidupan dan kematian atas manfaat dan mudharat, di dalam surat Al Baqarah :154. Bahwa ghaib itu sesungguhnya ada dan yang ghaib itu semua dari Allah Swt, maka dari itu kita selaku umat islam wajib mempercayainya, Sebab seluruh manfaat dan mudharat berasal dari Allah Swt, maka kehidupan dan kematian tak bisa membatasi manfaat dan mudharat kecuali dengan izin Allah Swt.

\section{DAFTAR PUSTAKA}

Al-Quran dan Terjemahannya, Surakarta: Pustaka Al-Hanan, tt..

Abu. Su'ud. Ritus-rites kebatinan. Cet I, II, Ill. Puslaka Nasional Ri : Katalog Dalam Negeri. Jakarta. 2000

Al-Hasani, Muhammad al-Maliki, Mafâhim Yajîb an Tushahhah, diterjemahkan menjadi Meluruskan Kesalahpahaman seputar Bid'ah Syafa'at Takfir Tasawuf Tawassul dan Ta'dzim, oleh Tarmana Abdul Qasim (Bandung: Rosda, 2001). Terbitan edisi Indonesia ini terdiri dari dua seri; Ali bn Nafayyi al-Alyani, Mencari Berkah Antara Yang Disyariatkan dan Yang Dilarang, (Jakarta: al-Qalam, 2002); KH Siradjuddin Abbas, 40 Masalah Agama I (Jakarta: Pustaka Tarbiyah, cet ke-30, 2000). Kekeramatan Makam (Ahand Amir Aziz, dkk)

Arjono Suryono, Kamus Antropologi. Jakarta: Persindo, 1985.

Abdurrahman al-Khumayyis, bin Muhammad, Syirik dan Sebabnya Jakarta Gema Press, 1994 
Betty R. Scharf, Kajian Sosiologi Agama. Yokyakarta: Tiara Wacana, 1995

Budhisantoso, Subur. Tradisi Lisan Sebagai Sebagai Sumber Informasi Kebudayaan

Dalam Analisa Kebudayaan, Jakarta: Depdikbud, 1989.

Bungin, Burhan., Analisa Data Kualitataif: Pemahaman Filosafis dan Metodologis ke

Arah Penguasaan Model Aplikasi. Cet.III, Jakarta Rajawali Press, 2009.

Culler. Jonathan,, Saussure. Penerjemah Rochayah dan Siti Suhati. Jakarta: Pembinaan dan Pengembangan Bahasa, 1996.

Felly, Usman dan Menanti, Asih. Teori-teori

Sosial Budaya. Jakarta: Proyek Pembinaan dan Peningkatan Mutu Tenaga Kependidikan Dirjen Dikti Depdikbud.1994.

Frank Cooley L, Atar And Throne In Centrl Aloluccan Society, di terjeinahlcan oleh Tim Sastra karya Iowan judul dan Tahata Cet.i; jakarta Sinar Harapan,1987

G. Ohorolla, H.M. Alanusia Maluku, Kebudayaan dan Keprihatian Alifuru .Soria Pembangunan, disampaikan. pada seminar nasional tentang Ambon, Ambon tanggal 30 Oktober 2006.

Geetz. Clifford, Abangan, Santri, Priyayi Dalam Masyarakat Jawa, Jakarta: Pustaka Jaya, 1989.

Giri, Wahana. Sesajen dan Ritual Orang Jawa, Sesajen, Upacara Tradisi, dan Ngalab Berkah Tinggalan Para Leluhur Yang Unik, Cet. 1; Jogjakarta: Nasari, 2010

Hadari Nawawi, Metode Penelitian Bidang Sosial. Yogyakarta : Gajah Mada University Press, 1998

Hendropuspito, Sosiologi Agama. Jakarta : Kanasinus, 1983.
Hilm, Mustofa. Ibn Taimiyah wa al-Tasawwuf. Iskandariah: Dar al-Da'wah, 1982.

Ihromi, O. Pokok-pokok Antropologi Budaya, (Jakarta: Yayasan Obor Indonesia 1999.

Koentjaraningrat, Kebudayaan Metalitas dan Pengembangan. Jakarta : Gramedia 1987.

Koentjaraningrat, Metode-metode Penelitian Masyarakat, Jakarta: PT Gramedia Pustaka Utama. 1994.

Koentjaraningrat, Kebudayaan, Mentalitas dan Pembangunan. Jakarta: PT Gramedia. 1994.

Koentjaraningrat, Sejarah Teori Antropologi II. Jakarta: UI Press. 1990.

Koentjaraningat, Beberapa Pokok Antropologi Sosial. Dian Rakyat, 1992.

Koentjaraningrat, Sejarah Teori Antropologil. Jakarta:Universitas Indonesia,1980

Koentjaraningrat, Kebudayaan Mentalitet dan Pembangunan, Cet. 1. Jakarta: Gramedia, 1974

M. Moeliono, Anton. Dkk. Tata Bahasa Baku Bahasa Indonesia. Jakarta: Departemen Pendidikan Nasional, Balai Pustaka, 2001.

Moleong, Lexy. J. Metode Penelitian Kualitatif. Cet.VI. Bandung :Remaja Rosdakarya, 2000

Nasution, S. Metode NaturalistikKualitatif. Cet.I.Bandung : Tarsito 1996.

Peursen, Van. Kebudayaan, Yogyakarta: Kanisius, 1988.

Plas. Daniel L. Seven the Ories of religion, Cet I. Yogyakarta: PT. Kalam. 2001

Roberston, Ronald. Agama; Dalam Analisis Dan Interprestasi Sosiologi, Jakarta: Rajawali, 1988

Saifudin, Fedyani, Ahmad. Antropologi Kontemporer Suatu Pengantar Kritis mengenai Paradigma. Cet II, Jakarta: PT. Prenada Media Group, 2006. 
Sesajen",sesajen-sebagai-sarana-untukmenghormat-dalam-pandanganbuddhisme. Pada;

https://vidhyvidyaningsih.wordpress.co m/2012/09/06/.html. Diakses pada tanggal 10 April 2016

Sunarto, Kamanto. Pengantar Sosiologi, Edisi Revisi, Jakarta: Lembaga Penerbit Fakultas Ekonomi Universitas Indonesia, 1993.

Suparwa, I Nyoman, Mitos Dalam Masyaraikat Dan Budaya Bali, Kajian Bentuk Bahasa Dan Makna Simbolik, (Bali: Fakultas Sastra Universitas Udayana, 1998

Soerjono Soekanto, Sosiologi Suatu Pengantar, Jakarta : PT Raja GrafindoPersada,1990, Soekanto, Soerjono, Sosiologi Suatu Pengantar. Jakarta: Rajawali Pers.2003.

Soemardjan dan Spoermadi. Soelaeman. Setangkai Bunga Sosiologi. (Jakarta: Lembaga Penerbit Fakultas Ekonomi Universitas Indonesia 1964.

Tashadi, dkk, Budaya Spiritual dalam Situs Keramat di Gunung Kawi Jawa Timur Jakarta: Depdikbud, 1994/1995.

Wa Nia, Dalam penelitian skripsi dengan Judul: "PIKADAWU " (Tradisi Menangkal Penyakit) Pada Masyarakat Dusun Amaholu Negeri Luhu Kecamatan Huamual Kabupaten Seram Bagian Barat, Universitas Pattimura: (Skripsi Prodi Ilmu Sejarah Konsentrasi Antropologi, Tahun 2012.

Warnaen, Suwarsih, "Pandangan Hidup Orang Sunda: Satu Hasil Studi Awal", dalam Harsja W. Bachtiar et all. (1988). Masyarakat dan Kebudayaan (Kumpulan Karangan untuk Prof. Dr. Selo Soemardjan). Jakarta: Penerbit Djambatan. 1989.
William L. Kolb dan Wilson, Logan, Sosiological Analysis. New York: Harcout, 1949. 